\title{
Miranda
}

Revue pluridisciplinaire du monde anglophone /

Multidisciplinary peer-reviewed journal on the English-

speaking world

1 | 2010

Variations on Darwin

\section{Christa Knellworth King, Faustus and the Promises of} the New Science, c.1580-1730

\section{Nathalie Rivère de Carles}

\section{OpenEdition}

\section{Journals}

\section{Electronic version}

URL: http://journals.openedition.org/miranda/453

DOI: $10.4000 /$ miranda.453

ISSN: 2108-6559

Publisher

Université Toulouse - Jean Jaurès

\section{Electronic reference}

Nathalie Rivère de Carles, "Christa Knellworth King, Faustus and the Promises of the New Science, $c$.

1580-1730", Miranda [Online], 1 | 2010, Online since 23 March 2010, connection on 16 February 2021.

URL: http://journals.openedition.org/miranda/453 ; DOI: https://doi.org/10.4000/miranda.453

This text was automatically generated on 16 February 2021.

\section{cc) (i) () $\Theta$}

Miranda is licensed under a Creative Commons Attribution-NonCommercial-NoDerivatives 4.0 International License. 


\title{
Christa Knellworth King, Faustus and the Promises of the New Science, $c$.
} 1580-1730

\author{
Nathalie Rivère de Carles
}

\section{REFERENCES}

Christa Knellworth King, Faustus and the Promises of the New Science, c.1580-1730, From the Chapbooks to Harlequin Faustus (Farnham: Ashgate, 2008), 208 p., ISBN: 978-0-7546-6133-7

1 Christa Knellworth King's Faustus and the Promises of the New Science, c.1580-1730, From the Chapbooks to Harlequin Faustus is a daring, clear and comprehensive work bringing out the impact of the figure of the scientist in both high and low brow culture. This book illustrates both the difficulty and the fruitfulness of the choice of an interdisciplinary approach mixing history, philosophy, and literature, scientific and popular culture. However, it mainly manages to successfully shed light on the complex evolutions of Faustus as the key figure behind the development of science in the early modern era, and its impact on societal and philosophical matters.

2 In her introduction King justifies her method and points out the "various generic guises" (1) she has chosen as materials for her study. Moving from oral tales to chapbooks to plays and contrasting them with epistemological writings on the self and the natural environment, she enhances the grounding of the Faustian myth in popular culture and cultural history. She identifies its role as a significant cursor of social stability. In order to prove her point, she chooses to ground her study in a rationalized historical approach to the early modern Faustus figure by tracing its genealogy through three key figures: Johann Sabellicus, a.k.a Georg / John Faust, the sensational travelling scholar, Faustus of Milevis, the emblematic representative of rational Christianity and Sabellicus as Christian Magician criticized in the works of Johannes Trithemius, Abbot of Sponheim, and Luther's Table Talks. 
3 Sabellicus was a travelling scholar with a bent on sensational spectacle involving criminal activities who gained fame through his evil deeds. He was also condemned as a necromancer and a fallacious user of magic bragging to possess the entire human knowledge as well as to be more powerful than Jesus. Luther's Table Talks refers to a magician and a necromancer he would have met in 1533 and described as an instrument of the devil and he even identifies him with the devil. Faustus of Milevis (350-400 AD) was a key protagonist of the Manichean theology and advocated a rationalist interpretation of the Bible. His writings did not survive but his ideas are contested by Augustine in his refutation of Manicheanism. Although King points out it is impossible to state firmly that the Faust Books were aimed to revive Manichean philosophy, "the Manichean idea that it is possible to refine and perfect the self through rational application of morality provides an exciting backdrop to a revisionary understanding of sin and damnation" (3). King stresses the verisimilitude of the author(s) of Spies' Faust Book or its lost precursors' knowledge of Faustus of Milevis and the belief in an "innate dignity of mankind" (4). She then establishes the links between the Faustian myth and the assertion of human aspirations in Pico della Mirandola's Oration on the Dignity of Man (1486) and Giordano Bruno's On the Infinite Universe and Worlds (1584).

4 King points at the fact that these are mainly the sources of the character but cannot be identified as faithfully emulated models. And this founds her interpretation and her approach to the Faustus figure as a unique web of influences characterizing the fluctuating relationship of society with scientific evolution. Faustus is not a copy of existing historical characters but a persona characterized by an existential and a textual isolation, as exemplified in both the English and the German Faust Books (Chapter 2). This paradoxical singularity of the Faustus figure is precisely, according to King, why Faustus can achieve the status of scientific mirror for all times: "The sixteenth-century Faustus stories were also enmeshed with the establishment of empiricism and the associated successes of scientific experimentation. [...] Beyond confirming that early modernity brought forth groundbreaking ideas concerning human existence and destiny, these studies describe it as a period that has been driven by heated conflicts over the definition of human nature" (7). Adopting Foucault's emergence of the rules of self-examination of early modernity, she posits Faustus as the mirror of the implantation of collective social norms into the conscience of the individual whose intrinsically collective essence jars with human individual aspirations. This necessity of introspection when faced with tyranny is identified by King as an internalized opposition and an inner defense mechanism which paved the way for the Romantic experience of the self, and she draws a parallel with Coleridge's metaphor of the air-sylph and the theory of potentialities: "the reason for the introspective gaze was to fathom the hidden potentials of the self" (8).

5 Faustus is thus portrayed as initiating the break between nature and the divine and the emancipation from medieval theological constraints advocated by Enlightenment thinkers. He is seen as a symbolic locus of conflict between the notion of positive revolution as perennial recurrence and the necessity of evolution through drastic changes. Nevertheless, King does not fall prey to an easy Faustian iconoclasm; she carefully keeps the actual impact of scientific discoveries on society and the secularization of society into perspective. She prefers to see the Faustus figure as the receptacle of the evolution in scientific exploration and of the conflict between the 
scholastic and the empiricist approaches. Hence she directly moves onto Marlowe's Faustus as the comprehensive mirror as "he identifies with none of the competing camps". This singularity of Marlowe's Faustus seems to have been King's methodological basis as she uses the "reciprocity between the history of science and culture" (19) to relate the slow shift in the relations between society, science, nature and religion during the early modern period and leading to the Enlightenment.

Chapter 2 focuses on the German Faust Book 1587 and the English Faust Book 1592 and analyses the conflict between human dignity and Calvinist defiance towards metaphysical curiosity, and thus paves the way for a close study of the core complexity of the Faustus figure in Chapter 3. The latter challenges the approach to the Marlovian hero as "overreacher" first exposed by Harry Levin. Dissociating Faustus from Tamburlaine, King decided to apply this interstitial method to her reading of both versions of Marlowe's play. She studies Marlowe's questioning of the possibility of a peaceful realization of both the self and society through his cunning confrontation of medieval aesthetics (the codes of mystery plays) and contemporary beliefs and assumptions. Drawing on her re-interpretation of the relationship between the A text and the B text versions of the play, she portrays Faustus less as a discussion of power than as a metaphysical discussion of imagination. Hence the use of magic in the play acquires a scientific dimension and embodies intellectual curiosity and the need for the exploration of one's environment (109).

7 Such an interpretation of Marlowe's Faustus leads King to link this approach to scientific enquiry to the intellectual landscape of the seventeenth century in Chapter 4. Through a diachronic approach centered on three very different thinkers and their works, Burton's Religio Medici (1642)-although Burton is hardly treated in this chapter and is preferred a long analysis of Thomas Browne instead-, Milton's Paradise Lost (1667), and Fontenelle's Entretiens sur la pluralité des Mondes (1686), King establishes the subsequent dissemination of this challenging view of the world at stake in the Faustian myth. While Faustian transgression is usually presented in a moral light and calls for some swift and stern punishment, its reading through the Miltonian lens particularly enhances its intrinsic positive nature: transgression as necessity in the quest for metaphysical truth. If Milton tones down this necessity as in need of a certain form of containment in later works, King prefers analyzing the notion of a restrained pursuit for knowledge through Fontenelle's work rather than Milton's. Thus she portrays a positive Faustus figure through Fontenelle's reassuring view of the scientist as an explorer of natural laws who does not have the power to control these very laws.

Having established the philosophical ramifications of the Faustus figure, King reinforces her epistemological exploration with instances from popular culture, and studies the particular re-appropriation of the Faustus figure on the Restoration stage and its renewed Harlequinades in Chapter 5. She moves back to the representation of the Faustus figure(s) in order to exemplify this slow change, and isolates an important feature which will lead to the most innovative part of her study in the last chapter: the tragi-comic dimension of Faustus. King insists on the liminal essence of Faustus, a character exploring "the ambiguous interspaces between success and failures" (20). This interstitial reading of the protagonist culminates in her study of the farcical interpretations of Faustus in Chapter 5. The tragic-comic potential of Faustus found its best aesthetic expression in eighteenth-century satire. Retaining Faustus' craving for 
knowledge, the Enlightenment mainly used Faustus as a critical instrument in the study of the moral and social impact of experimentation.

Christa Knellwolf King's method is interesting as it is based upon a heterogeneous vision of the Faustus figure as emblem of the development of the New Science. She helps redesigning the approach to the character of Faustus in a more positive light by juxtaposing the different levels of early modern thinking on and cultural expressions of mankind's pursuit of knowledge. Although sometimes the indecision between a synchronic and a diachronic approach and the disappearance of certain footnoted references from the bibliography can be confusing, King's clear prose leads a captivated reader through the arcane of early modern anxieties over knowledge and the power of the human mind. King's approach is daring and fruitful in giving a comprehensive overview of the unexpected ramifications of a controversial myth.

\section{INDEX}

Keywords: Faustus figure, scientific evolution, Manichean philosophy, natural law, Experience of the self, Faustian iconoclasm, Early Modern Era, Enlightenment, representation of the scientist, drama

Mots-clés: figure faustienne, évolution scientifique, philosophie manichéenne, loi naturelle, expérience de soi, iconoclasme faustien, lumières, représentation du savant, théâtre, époque moderne

\section{AUTHORS}

\section{NATHALIE RIVÈRE DE CARLES}

Maître de conférences

Université de Toulouse II-Le Mirail

nrivere@univ-tlse2.fr 